\title{
XENOTIME FROM MORRUA, MOZAMBIQUE
}

\author{
Th. G. Sahama, Oleg v. Knorring and \\ Pentti Rehtijärvi
}

\begin{abstract}
Sahama, Th. G., v. Knorring, Oleg and Rehtijärvi, Pentit 1973: Xenotime from Morrua, Mozambique. Bull. Geol. Soc. Finland 45, 67-71.

Xenotime, found as well formed crystals in a heavy mineral concentrate from the Morrua pegmatite mine in Mozambique, was studied. The mineral occurs in the sample in two generations, clearly distinguishable from each other. The first generation crystals are turbid with varying color and are dominated by the faces (110) and (001). The second generation crystals are yellow, entirely transparent and exhibit the sequence (100)-(301)-(101) (001) in the development of the crystal faces. The mineral is highly yttrian with an atomic ratio yttrium/lanthanides $=78: 22$ and, in the relative abundance of the lanthanides, shows a strongly pronounced maximum of gadolinium. X-ray and optical data and density are given.
\end{abstract}

Th. G. Sabama and Pentti Rebtijärvi, Dept. of Geology, Snellmanink. 5, SF-00170 Helsinki 17, Finland.

Oleg v. Knorring, Dept. of Earth Sciences, Leeds LS2 9JT, United Kingdom.

\section{Introduction}

When visiting in 1967 the Morrua pegmatite mine in the District of Zambezia, Mozambique, one of us (Th. G. S.) received a sample of a heavy mineral concentrate produced by the mine. The grain size of the concentrate averaged $1 \mathrm{~mm}$. The main minerals found in the sample were black tantalite-columbite with a density of $d=$ 6.55 (Berman balance), red manganotantalite, monazite and xenotime, all in more or less well developed, euhedral crystals. Some lepidolite inclusions can occasionally be seen in the crystals of these minerals. A few broken pieces of reddish garnet, irregular grains of bismutite and some octahedra of microlite were also found. The red manganotantalite from the Morrua mine has been described by Harrison et al. (1966) and by v. Knorring et al. (1966). In the concentrate, both red and black tantalite often occur intergrown with monazite and clear xenotime. The brownish yellow monazite shows a density of $d=5.41$ (Berman balance). The zircon varies from reddish yellow to green in color. No parallel growth of zircon and xenotime, as illustrated by, e.g., Ito and Sakurai (1947), could be detected in the morphology of the crystals. Xenotime does not appear to have been previously found in Morrua and is not mentioned by Behier (1957) in his list of Mozambique minerals. However, 

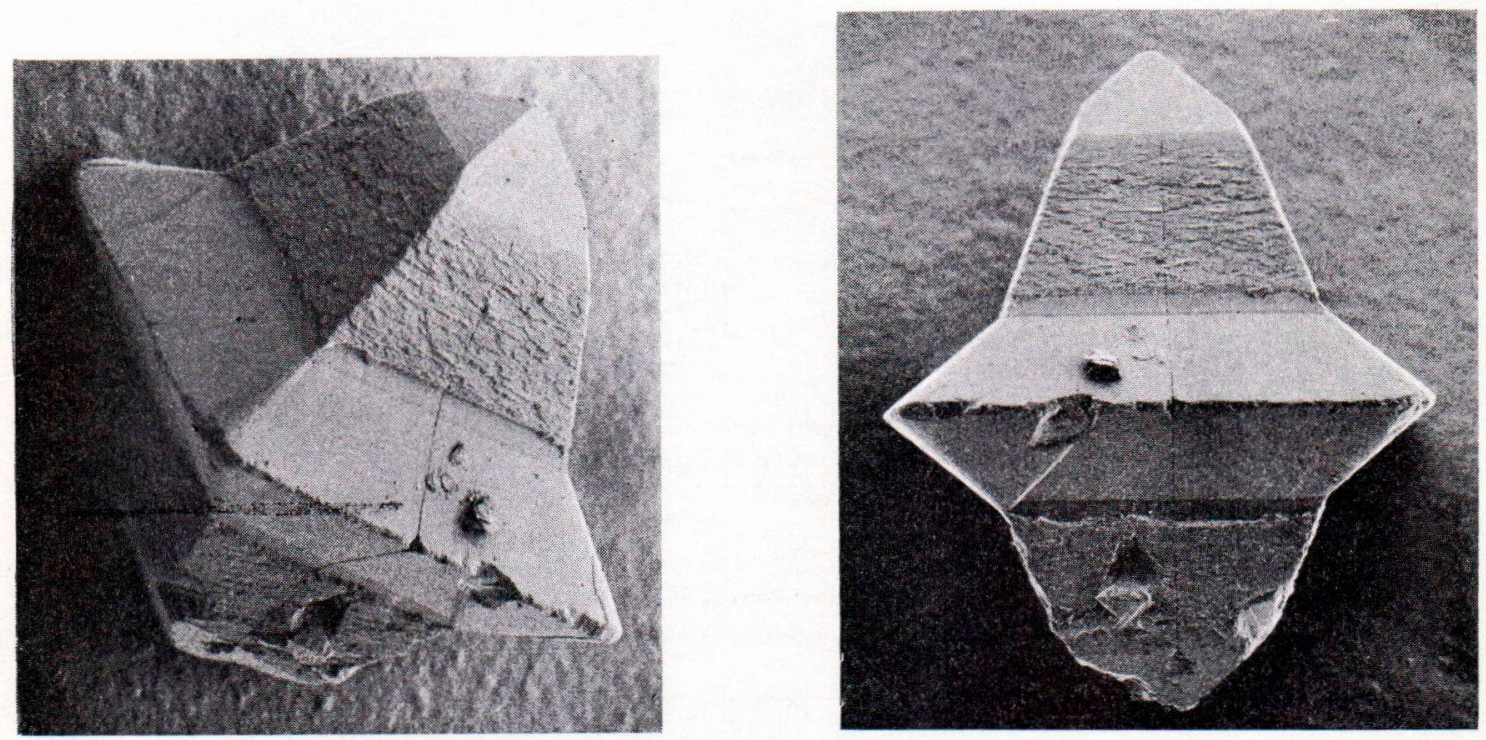

Fig. 1. Scanning electron micrographs of a xenotime crystal from Morrua, Mozambique. Length of crystal $1 \mathrm{~mm}$.

v. Knorring $(1962,1970)$ has recorded xenotime from Namivo pegmatite in the same general area. Here, greenish xenotime is found associated with cyrtolite, monazite and columbite in the clevelandite-lithian-mica zone.

Being available only as a heavy mineral concentrate, the mode of occurrence of these minerals in the pegmatite body can not be described.

On inspecting the concentrate under a binocular microscope, a few xenotime crystals of a habit illustrated in Fig. 1 were found. Because, to the knowledge of the authors, such a habit of xenotime has not been described in literature, the mineral was subjected to closer study.

\section{Crystal form}

Most of the xenotime crystals display the habit illustrated in Fig. 2, No. 5. These crystals are more or less turbid with a color varying from yellow to slightly reddish. They represent ap-

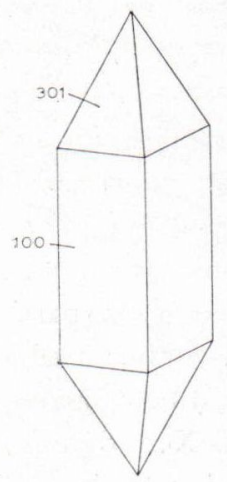

1

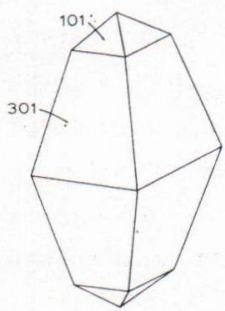

2

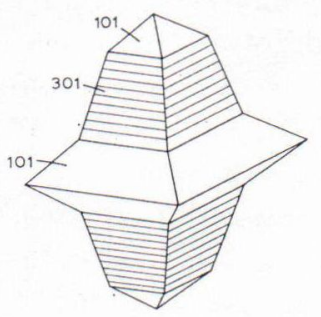

3

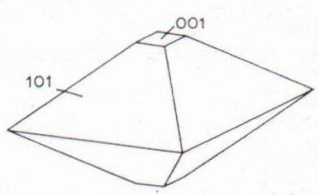

4

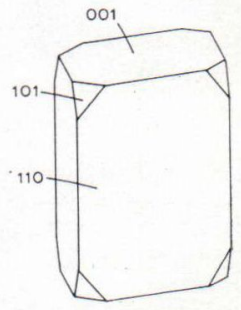

5

Fig. 2. Variation in crystal habit of xenotime from Morrua, Mozambique. 
parently an early generation of the xenotime crystallization, called first generation in this paper. The crystals are characterized by the predominance of (110) and (001). The (101) face is poorly developed. In very rare instances a narrow pyramidal face was observed, (211).

On the other hand, a small number of the xenotime crystals are transparent, without inclusions and uniform yellow in color. These crystals show invariably sharp crystal forms, idealized examples of which are illustrated in Fig. 2, Nos. 1-4. The crystals appear to have crystallized in open wugs and are here considered to represent the second generation of xenotime crystallization.

The orientation of crystal forms in Fig. 2 and the indices assigned to the faces were based on $\mathrm{X}$-ray precession photographs.

The second generation crystals never show the face (110) and rarely (100). These two faces can easily be distinguished from each other under a binocular microscope by the traces of cleavage planes which are parallel to (100). In some instances the second generation crystals exhibit rough planes simulating (110), but with strongly developed growth hillocks which reflect light from a plane parallel to $(100)$. It appears that if a first generation crystal continues to grow in second generation conditions, the face (110) will disappear and (100) is formed.

All intermediate steps can be found between the ideal forms of Nos. 1-4, Fig. 2. A study of these intermediate crystal habits shows that the succession Nos. $1-4$ as given in the figure actually corresponds to the order of growth of the various faces. Starting from the No. 1 habit, the face (301) increases in size at the expense of (100). A small face (101) is simultaneously developed and the habit reaches that of No. 2 . With continued growth the face (101) becomes dominant. Further growth of this face in No. 2 starts laterally from the horizontal edges in the middle of the crystal leading to the shape of No. 3. On (301) of No. 3 a horizontal striation is characteristic. With a scanning electron micro- scope it can be seen that this striation is caused by a stepwise development of traces of (101). The striated face (301) reflects light in the same position as the top face (101). No. 4 represents the last stage, with a small face (001) sometimes visible. No twinned crystals were found.

\section{Separation}

For chemical analysis the concentrate was separated with a Clerici melt on a steam bath. Only manganotantalite, tantalite and monazite sink in the melt, whereas zircon and xenotime remain floating. After cooling and solidification of the melt, the floating part was dissolved with hot water. Being clearly paramagnetic, xenotime was purified from contamination with an isodynamic magnetic separator. The few crystals of zircon $e t c$. which still remained in the xenotime material were picked out under a binocular microscope. Second generation crystals of xenotime were picked out by hand for study.

\section{Chemical composition}

The first generation xenotime was chemically analyzed by one of us (O. v. K.). The material used for the analysis was dissolved by digesting with sulfuric acid. In this way, the slight zircon contamination and the few quartz inclusions in the xenotime crystals were left as an insoluble residue. The result of the analysis, reproduced in column 1 of Table 1, corresponds closely to the theoretical xenotime composition.

The amounts of the rare earth elements were determined on the mixture of oxides from the first generation xenotime. The analysis was made by XRF technique and atomic absorption spectrometry. The results are given in column 2 of Table 1 . The relative abundances of the lanthanides are shown in Fig. 3. 
TABle 1.

Chemical composition of xenotime from Morrua, Mozambique

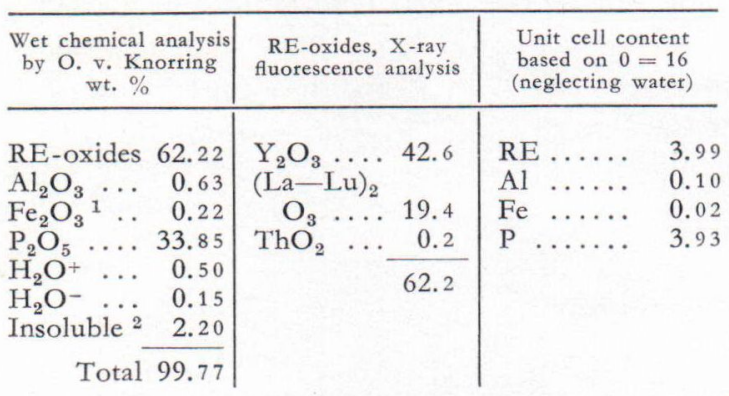

1) Total iron.

2) Admixed zircon and quartz.

Inspection of the data in Table 1 reveals that the first generation xenotime from Morrua is highly yttrian. The atomic ratio of yttrium to the sum of lanthanides is $78: 22$. This value appears to be among the highest known for xenotime. The thorium content is low.

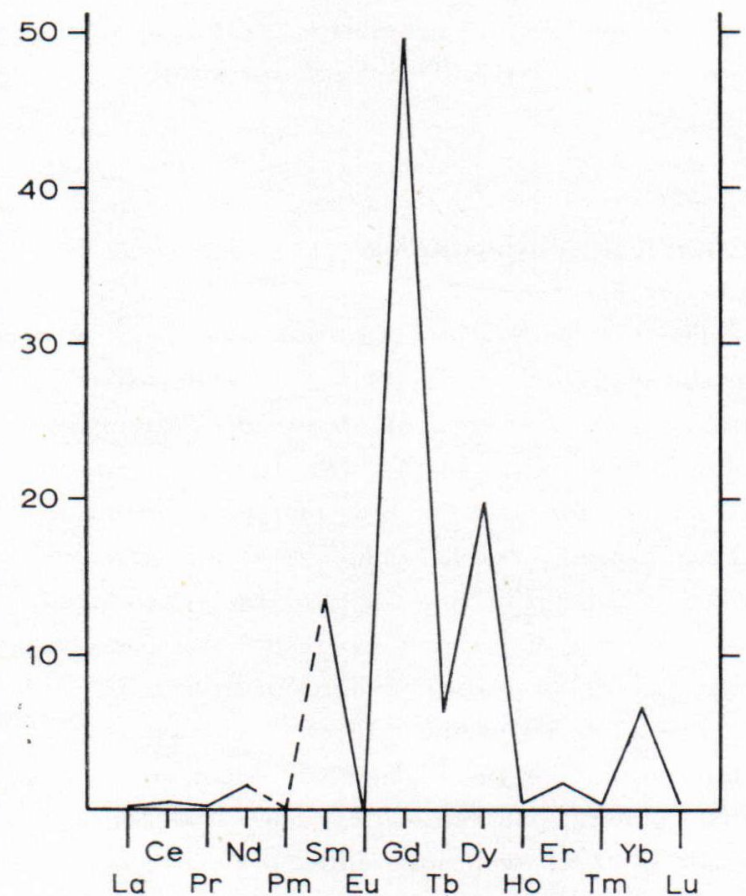

Fig. 3. Relative abundance of the rare earth elements $\mathrm{La}-\mathrm{Lu}$ in the first xenotime generation of Morrua, Mozambique.
Fig. 4. Schematical crosssection of a xenotime crystal showing the lateral growth of the (101) faces. Core blank; lateral growth shaded.

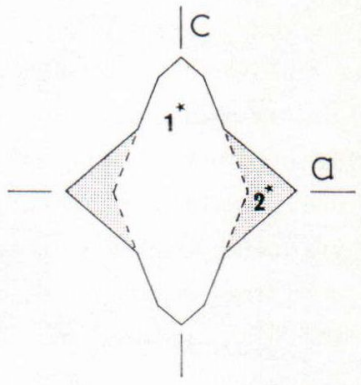

The literature dealing with the relative abundances of the lanthanides in xenotime has been compiled by, e.g., Vlasov (1966) and Adams (1969). The available data commonly indicate a predominance of either $\mathrm{Yb}$ or $\mathrm{Dy}(+\mathrm{Er})$. As yet, the Morrua xenotime appears to be unique in exhibiting a strongly pronounced maximum in Gd. This fact supports the view that the relative abundances of the lanthanides depend on environmental factors during the crystallization as well as on the structure of the crystallizing mineral.

A xenotime crystal with the shape of No. 3 in Fig. 2 was subjected to a qualitative microprobe test. A schematic cross-section of such a crystal is given in Fig. 4. At the points marked No. 1 and No. 2 yttrium and the lanthanides were tested. It was found that the late lateral growth of the crystal (point No. 2 in Fig. 4) is clearly enriched in lanthanides as compared with the core of the crystal (point No. 1). The core showed higher yttrium content than did the lateral growth. It appears that the ability of taking up lanthanides in the xenotime structure increased towards the late stages of the crystallization. No marked differences in the relative abundances of the lanthanides were found between the two points.

\section{X-ray crystallography}

The systematic extinctions revealed by a series of X-ray precession photographs of the first generation mineral indicate the space group $I 4_{1} /$ amd 
of xenotime. The X-ray powder pattern was recorded with the Philips wide angle goniometer. The result agrees with known values for xenotime and is not reproduced here. The unit cell dimensions calculated from the powder pattern are: $a_{\mathrm{o}}=6.913 A, c_{\mathrm{o}}=6.045 \AA$ (both \pm 0.005 $A)$. These values lie at about the upper limit reported for xenotime.

\section{Optical properties and density}

The refractive indices measured by the immersion method for the second generation mineral are: $\varepsilon=1.711, \omega=1.810$ (both \pm 0.003 ). $\omega-\varepsilon=0.099$ (calculated). These are somewhat low for xenotime.

The density was determined for the second generation mineral as $d=4.58$ (Berman balance). For the first generation mineral the value $d=$ 4.59 was calculated on the basis of the chemical analysis. The two values are virtually identical.

Acknowledgements - The authors are indebted to Mr. J. D. Cabral (Morrua Mine) for the sample studied, to Mr. Esko Saari (Kemira Co., Oulu, Finland) for the analysis of the rare earth oxide mixture and to Dr. Jaakko Siivola (Geological Survey of Finland) for the microprobe tests.

\section{REFERENCES}

AdAMs, John W. (1969) Distribution of lanthanides in minerals. U. S. Geol. Survey Prof. Paper $650-$ C, p. C38.

Behier, J. (1957) Minerais da Provincia de Mocambique. Servicos de Industria e Geologia, Boletim 22.

Harrison, R. K., Horne, J. E. T. and Atrin, D. (1966) Manganotantalite from Morrua, Mozambique. Bull. Geol. Surv. Great Britain, No. 25, p. 77.

Ito, T. and SAKuraI K. (1947) Wada's Minerals of Japan, Third Edition, Miner. Inst. Univ. Tokyo, p. 286.

v. KNORRING, Oleg (1962) The mineralogical aspects of the pegmatites of the Alto Ligonha area, Mozambique. 6th Ann. Rep. Res. Inst. African Geol., Univ. Leeds, p. 7. v. Knorring, Oleg (1970) Mineralogical and geochemical aspects of pegmatites from orogenic belts of equatorial and southern Africa. In: African Magmatism and Tectonics, Edited by T. N. Clifford and I. G. Gass, Oliver and Boyd, Edinburgh, p. 157.

- Sahama, Th. G. and SAari, Esko (1966) A note on the properties of manganotantalite. C. R. Soc. géol. Finlande, No. 38, p. 47.

Vlasov, K. A. (editor), (1966) Geochemistry and mineralogy of rare elements and genetic types of their deposits. Volume II. Mineralogy of rare elements. Translated by Z. Lerman, p. 230.

Manuscript received, July 21, 1972. 